\title{
THE IDENTITY, RIGHTS AND CHALLENGES OF CATHOLIC KNIGHTS IN THE CHURCH
}

\section{Anthony B. Chiegboka \& Elizabeth O. Ezenweke}

\section{Abstract}

The desire for honours is prevalent in the human societies and also in the Church. Knighthood is of ancient origin. It is always a reward for both civil and military services. It is within the context of recognition for distinguished services and as a means of rewarding loyalty rendered that the Catholic Church considered it expedient to appropriate within the ecclesiastical circle what was of secular origin. In the Church we have Knights of Papal and diocesan/local status. They are lay members who are outstanding in their defence of faith and the Church. Since these knights enjoy dual citizens in both the Church and civil communities, we intend to see the order of knights in their identity, typology, rights and challenges in both the Church and civil society.

\section{INTRODUCTION}

Therefore, put on the whole armour of God, that in the evil day, you may resist and stand your ground, making use of all your weapons. Take truth as your belt, justice as your breastplate, and zeal as your shoes to propagate the Gospel of peace. Always hold in your hand the shield of faith to repel the flaming arrows of the devil. Finally, use the helmet of salvation and the sword of the Spirit, that is, the Word of God. Pray at all times as the Spirit inspires you. Keep watch, together with sustained prayer and supplication for all the brothers (Eph 6: 13-18).

With these noble words from the Scriptures that actually capture the identity and challenges of Knights in the Church which Paul, the ambassador to the gentiles addressed to the Christian community at Ephesus, I intend to discuss about this extraordinary group among 
the laity, who because of their zeal for the Lord and their outstanding contribution to Christian witness were raised to the noble status as Knights.

Many of them, if not all, are the foundation members and resource persons for the emergence of both Catholic Christianity and Knighthood in the Church both at the Eastern Regional and National levels. This is true when we take cognizance of the fact that the first recipients of Papal Knighthood, the establishment of both the Knighthood of St Mulumba (KSM) in 1953 and Knighthood of St John's International (KSJ) in 1976 were through the committed involvement of lay persons from the Eastern region. The inaugural ceremonies for the above two orders were also performed in the same region. For KSM it took place at Owerri on June 14, 1953 through late Bishop Joseph Whelan of Owerri while for KSJ it was on Pentecost Sunday, June 6, 1976 at Enugu through Late Bishop G. M. P. Okoye, CSSp.

We shall address the nature of the Church, its composition with emphasis on the indispensability of the laity in the Church. We shall then take up issues related to the identity/Typology, rights and challenges of the knights in the Church.

\section{THE NATURE OF THE CHURCH}

The Fathers of the Second Vatican Council aware that the Church is threandric (i.e. divine and human), instead of defining the Church, they rather described the Church through some images drawn from the Scriptures. In the their Dogmatic Constitution on the Church, Lumen Gentium LG (1964), the members described the Church as Sheepfold of Christ (John 10:1-10); flock of God with Christ as Shepherd (Ezek 34: 1ff; John 10:11-15); God's field (Rom 11, 16-22); God's building (1 Cor 3,9); God's household(1 Tim 3,15); Temple (1 Pet 2,5); bride ( $\operatorname{Rev} 19,7 ; 21,2 ; 22,17)$ and finally as sacrament of salvation, people of God and communion (Vatican
Council II, 1964: LG 6, 9, 1, 7, 13, 48). However, John Paul II (1983) was to affirm clearly that, "Foremost among the elements which express the true and authentic image of the Church are the teachings whereby the Church is presented as the People of God (LG 2) and its hierarchical authority as service (ibid. 3); and further teaching which portrays the Church as a communion...." (p. xiv).

The Church as People of God implies common lineage and consanguinity emerging from the cross and side of Christ and the waters of baptism (Chiegboka, 2007). This image is used in both the description of the diocesan family (cann 369; 837,1); the parish (can 515) and extends to the validly baptized or received persons into or in full communion with the Church (can 11; 205; LG 12) and in solicitude, those outside the faith or in partial communion with the Church (can 383; 771; 755; 844; 529; LG 13-17).

The Church as Communion emphasis the image of an organic bond and demands of unity which is sealed by the Eucharist (Chiegboka, 2007;1 Cor 12:27; 10, 16). This later image of communion helps us in discerning the full membership of the Church; engenders spiritual solidarity in both the personal, structural and administrative relationships, and finally, the even participation and co-responsibility of all members within the rank and file of the Church especially with regard to the apostolate. This communion is needed for full membership in the Church (can 205), for office in the Church (can 149) and assumption and exercise of offices (cann 380; 833; 675), for participation of the laity in the Church Councils (can 512), for the operation and removal of pastors (cann 529, 1741), etc.

\section{THE COMPOSITION OF AND INDISPENSABILITY OF THE LAITY IN THE CHURCH}

This Church as both people of God and communion is composed of clerics, religious and laity. The clerics are the Bishops, Priests and Deacons (John Paul II, 1983:cann 207; 1008; 1009; Vatican Council 
II: LG 18-29), while the Religious are drawn from both the clergy and the laity (can 207) but marked with unique identity of vows or promises of evangelical counsels of obedience, poverty and chastity (John Paul II, 1983: cann 573-575; 598-602; 607; 673), and the laity are those who are not clerics (LG 31).

The lay members of the Church constitute about $99 \%$ of those that make up the Church (Ojo, 1998; Dodo, 1992). As already indicated above, the laity are those who are not clerics (LG 31; can 207). In the Church, through sacrament of baptism they enjoy the status as physical persons (can 96), members of the people of God (can 204), equal in dignity (can 208), with rights and privileges pertaining to all other members (cann 96; 208-223) and specific to their state (can 224-231).

In the decree on the Apostolate of the Laity, Apostolicam Actuositatem, AA the Fathers of Second Vatican Council (1964) reiterated that "the Christian vocation is the vocation to the apostolate"(no 2), and as such the lay members through baptism are configured to Christ, share in the common priesthood of all the baptised and given the responsibility to participate in their own way and according to their condition and office in priestly, prophetic and kingly office of Christ and mission of the Church (cann 204, 208, 759; 774; AA 10). Just as Pius XII (1957) in his address to the Second World Congress of the lay Apostolate in 1957 observed: "It would be a misunderstanding of the nature of the Church and her social character to distinguish in her, a purely active element, the ecclesiastical authorities and on the other hand a purely passive element, the laity" (p. 10).

It is, therefore, out of place to consider the laity as visitors in the Church or for the laity to consider the Church as Uka Fada (i.e. Church of the Clergy). All members, clergy, religious and laity are called to the apostolate and to the vineyard of the Lord although at different times and for different functions but for one unique prize, eternal life and union with God. On this basis the Fathers of the Second Vatican Council were explicit in their words in various places on the indispensability of the Laity and their apostolate in the Church and beyond viz: "Indeed, the Church can never be without the lay apostolate; it is something that derives from the layman's very vocation as a Christian" (AA 1). And emphatically,

The Church is not truly established and does not fully live, nor is it a perfect sign of Christ unless there is a genuine laity existing and working alongside the hierarchy. For the gospel cannot become deeply rooted in the mentality, life and work of a people without the active presence of lay people. Therefore from the foundation of the Church very special care must be taken to form a mature Christian Laity. The lay faithful belong fully both to the people of God and civil society. (Ad Gentes 21).

The lay members of the Church are therefore citizens of the Church and the Society. They are open to the apostolate of the Church and her mission both as individuals and within their groups (AA 15-22). The laity operates both Individual and Group Apostolate.

\section{THE IDENTITY AND TYPOLOGY OF KNIGHTS IN THE CHURCH}

\section{The Identity of Knights}

As rightly observed by Omutah (2004), "In the heart of every man and woman of all ages, cultures and societies, there is a genuine craving for honour, dignity and respect. This for the most times is translated into names and titles. In many societies there exists titles of roles and functions.. There are also titles of honours or decorations" (p. 1). In Nigeria, especially in our South East we see these trends and cravings and syndrome for traditional (like 
chiefs, ichies, nze na ozo etc) and ecclesial (knighthood, life member, patrons, matrons, ezinne etc) titles of honours, awards, recognitions that ensures social esteem and prestige.

Knighthood is not of ecclesiastical origin (Omutah, 2004; Okafor, 2001; Unegbu, 2002), but of secular medieval feudal society as seen in its etymological rendering by Okafor (2001): "The word Knight in English is equivalent to French Chevalier or German Ritter, which is a title of honour bestowed for variety of services, but originally in the European middle ages a formally professed cavalry man". (p. 60). According to Webster's Encyclopedic Unabridged Dictionary of the English Language (1989), a knight is "a mounted soldier serving under a feudal superior"; "a man usually of noble birth"; "a man upon whom a certain non hereditary dignity corresponding to that of the medieval knight is conferred". (p. 791). In relation to the above meaning, The New Webster's Dictionary of the English Language (1995) added that a knight is "a man given the rank of knighthood by the British Monarch in recognition of merit, esp. in public service. He has the titles 'Sir," his wife having the title of 'Lady'"' (p. 543).

It is within the context of recognition for distinguished services and as a means of rewarding loyalty rendered that the Catholic Church considered it expedient to appropriate within the ecclesiastical circle what was of secular origin (Omutah, 2004). In the Church, the Holy See grants Papal Honours to all members of the Church, i.e. the Clergy, Religious and Laity. These honours include for instance for secular priests: Chaplain to His Holiness, Prelate of Honour to His Holiness, Apostolic Protonotary Supernumerary and so forth; for Religious Men and Women: Benemerenti Medal, Cross Pro Ecclesia et Pontifice; and for Lay Persons: Plain Order (Collar Chain, Grand Cross), Order of St Gregory the Great (Grand Cross, Commander with Plaque, Commander, Knighthood), Order of St Sylvester (Grand Cross, Commander with Plaque, Commander, Knighthood),
Benemerenti medal and cross Pro Ecclesia et Pontifice etc.

In essence, Knights are principally Christians and adult male members of the Church. They belong to the lay members of the Christian faithful. They enjoy this status by reason of baptism (John Paul II, 1983: cann 96, 204). Ngwoke (1987), corroborates thus:

Born into the Church not by natural generation, by status or desire but by the only divinely established means of this spiritual birth namely baptism (can 96). It is that sacrament that confers on the baptized his ecclesiastical personality, a subject of ecclesial rights and duties Possession of these rights and duties is however in degrees. (pp. 1-2).

By Baptism the knights are identified as physical persons (can 96) and members of the people of God (can 204) and enjoy fundamental equality in the Church (can 208) and with their partners in marriage (can 1135). In the Church they are also seen as members of the Church Councils and Committees; Vice Chairmen and Secretaries of Parish Councils and many committees and pious societies in the church (even where women are greater in number in such societies), Catechists, etc. In the Society they are the family heads and most often the breadwinners. They are the decision makers in Igbo cultural societies. They operate in Kindred, Village, Town Unions, Age grades, Igwe-in-Councils, Clubs and Business set ups. You get them in Government circles as leading members of the Government in all sectors both as Chief Executive, Assembly men/Legislators, Party officials, Government workers, leaders of the various labour Unions etc.

Papal awards of knighthood belong to those coveted honours given to the lay members of Christ's faithful people (Omutah, 2004). It is granted directly by Pope himself out of his own will (motu proprio), or at the request of the Diocesan Bishop or Vicar Generals 
(with the authority the Bishop) who are ordinaries in law (cann 134, 479). The request or petition should be accompanied by curriculum vitae of the candidate (age, profession, family and social situation, and an accurate description of award requested and those earlier received from the Holy See) and sent to the Apostolic Nuntiature for the necessary 'nihil obstat'. This will be sent to the Dicastery (Congregation for the Evangelization of People) whose duty it is to transmit the information to the Secretariat of State for final approval.

To be qualified for presentation for the award especially of Papal Knighthood, one should have "demonstrated the highest ideals of Christian faith by exemplary living in their families and various endeavours. In other words, they are to be practical Catholics" (Omutah, 2004: 52). A knight should be one that is marked by love of God and the Church and one who is zealous and committed in fidelity to the Church and in Christian witness. For Cardinal Agostino (in Shiweobi 1992), a knight is "a man who intends to place himself at the service of a noble and difficult cause, a pure and arduous ideal; fighting evil, promoting good, defending the weak and the oppressed against injustice. Becoming a Knight does not merely mean receiving title of honour, even though it is well deserved, it presupposes a solemn commitment" (p. 10). The identity of the Catholic Knight is further seen in the tribute of Francis Cardinal Arinze (in Obi, 1985) to Mr William Onuchukwu the very first group of Papal Knights in Nigeria who he described as "a faithful father of the family, lover of his fellow man, truly believing Christian, sign of perseverance in the midst of trials, a man of dignity in good times and in bad, in poverty and in riches." (p. 170).

\section{Typology of Knighthood in Church}

In ancient times especially for persons directly involved in the defence of the Holy land from Islamic invasion, we have Knights of Malta or Knights of Hospitallers Order of St John of Jerusalem and the Equestrian Order of the Holy Sepulchre of Jerusalem. There are some of those ancient Knighthoods that still exist and some that do not exist any longer. For our convenience, we intend to distinguish knighthood in terms of its creation or principal locals of its conferment. We distinguish between Pontifical and Diocesan Orders of Knights and awards. The later may have both national and internationa characters and outreach.

In relation to the first group, we distinguish two forms of Papal awards, viz:

(a) Pontifical Order of Papal Knighthood

* The Supreme Order of Christ

* The Order of the Golden Spur

* The Order of Pius IX

* The Order of St Gregory the Great

* The Order of St Sylvester

(b) Award of Papal Medalist and other Papal Decorations

* Pro-Ecclesia et Pontifice

* Benemerenti

* The Golden Rose

* Gentleman of His Holiness

* The Stewards of St Peter

* The Pontifical Academician

* The Lay Assistant to the Throne

And for the Second Group, we have the Knights of the Order of St Columbus; Knights of the Order of St Mulumba, Knights of the Ancient and Noble Order of St John's International and Knights of St Christopher.

We intend to make a brief exposition of few of them from both groups, especially ones that are prevalent in our nation and these are Papal Knights of St Gregory and St Sylvester and then Knights of St Mulumba and St John (and very briefly from the Anglican Communion, Knights of St Christopher and the Good Shepherd). 
The Papal Knights of the Order of St Gregory was founded by Pope Gregory XVI on September 1, 1831 with two divisions of civil and military classes. It was instituted to honour Pope St Gregory the Great and also to reward men of outstanding fidelity to both the Holy See and the Prima Sedes (first See/Supreme Pontiff) and indeed those persons marked by the fame of their virtue, their social standing, their brilliant accomplishment, their administrative ability and enjoy very good esteem among honest people (Bull, 1982). It was originally arranged into four classes but later on May 30, 1834 reduced to three viz: The Knights of the Great Cross, Knights by Commendation and Simple Knights. They have unique insignia/regalia.

The Papal Knights of the Order of St Sylvester was founded by same Pope Gregory XVI on October 31, 1841 to replace the ancient Order of the Golden Spur. Just like Knights of St Gregory it is in three Classes with unique insignia/regalia. Nigerians witnessed the first presence of Papal Knights in 1956 of William Onuchukwu, Paul Anaekwe and Joseph Odogwu.

The Order of the Knights of St Mulumba is linked with Rev Fr Anselm Abraham Ojefua (1912-1988), a Nigerian priest and monk who founded the order and served as the first Supreme knight of the Order. With his experience of the services rendered by Knights of St Columbus that existed since October 1881 in America (through the agency of Fr Michael J. McGinney), he decided on his return to Nigeria to form a similar institution to help lay Catholics to defend and practice their faith with outstanding solidarity and confraternity. For Fr Ojefua writes Omutah (2004), "This great priest discovered to his dismay that great numbers of Catholics drifted away from their faith. The reasons not far-fetched, secret cults or societies like freemason, Amoc, Ogboni, lodge, among others, were being used against them in politics, commerce and industry". (p. 22). The Order was named after Matthias Kalemba Mulumba who with many others (many of them youths) suffered matrydom in Uganda during the time of King Mwanga. Mulumba was outstanding in his courage, zeal and steadfastness to the Christian principles and sexual morality. They suffered martyrdom and were canonized as the first African martyrs by Pope Paul VI in 1964. Thus with the blessings and approval of the Catholic Bishops' Conference of Nigeria in 1953, the Order was formally inaugurated at Owerri on June 14, 1953 by Bishop Joseph Whelan with 23 foundation members among them was Dr George Akabogu (Shiweobi, 1992: 15; Omutah, 2004: 23; Okafor, 2001: 97-101).

The Ancient and Noble Order of St John's International was founded in 1048 at Naples in Italy. It emerged in New Yord, USA in 1886. It made in-roads into Nigeria through the committed effort of Mr Kevin N. O. Ejiogu who entered the Order in 1961 while domiciled in Monrovia, Libreria. He introduced it in Nigeria in 1976 after preliminary blessings and approval from the then Bishop of Enugu, Rt Rev G. M. P. Okoye, CSSp. The formal inauguration took place at Enugu on Pentecost Sunday, June 6, 1976 with 25 foundation members.

The Knights of St Christopher is the brand of Anglican Communion in Nigeria. It was initiated through the then Bishop on the Niger, Rt Rev Jonathan Onyemelukwe in 1978. Ever since then it has spread like a wild fire across various diocese in Nigeria (Unegbu. 2002).

\section{THE RIGHTS OF THE KNIGHTS IN THE CHURCH}

Rights are generally entitlements due to a person which he can demand. It can be: Natural (deriving from the very nature of the person as a human being); Legal (attributed to the person on the basis of legislation) and Acquired (belonging to the individual on completion of acts that confer a title). Our concern will be with legal rights. Rights and Responsibilities and obligations are considered as two sides of the same coin. We have decided to discuss it first because of the well known situations of abuse of human rights 
current in our society and even in the church in various dimensions. The code (John Paul II, 1983) emphasized that: "The exercise of rights in the Church are regulated by the common good of the Church, the rights of others and the obligations to others". (can $223, \S 1)$.

The rights of the Knights are drawn from the general presentations of the bill of rights specified in the new Code of canon law (cann 208-222); Right to equality (can 208); Right to means of holiness and spiritual assistance (cann 210; 213; 276, §2, $2^{\circ}$; LG 39,33 ); Right to spread divine message of salvation (cann 211; 204); Right to freely establish and direct associations (can 215; 278) or initiate apostolic actions (can 216); Right to Christian education (can 217; 279) and freedom to research (can 218; GE 10; GS 62); Right to petition (can 212, §2 \& 3) and to due process (can 221); Right to good reputation and privacy (can 220; LG 28); and finally Right to immunity from any kind of coercion in choosing a state of life (cann 219; 214; 748, §2; GS 26, 29). The exercise of these rights are limited by the person's condition, rights of others and duties to others, the degree or extent of communion the person has with the Church, ecclesiastical censures and regulations in view of common good (cann 223; 93).

From the foregoing, we witness a landmark in the Church's legislation with the above extensive corpus on bill of rights. The canonists continue to ask like Coriden (1990), "What Became of the Bill of Rights?" (pp. 47-60). In other words, there is need, in the Church to create an adequate avenue for the promotion and protection of the rights of the faithful or else they amount to "empty and meaningless exercise," (Paprocki, 1990: 430) i.e. "without credible and effective procedures to vindicate rights, 'all the reservations of particular rights or privileges would amount to nothing."' (Beal, 1991:13).

All juridical system that recognize or attribute subjective rights should endeavour to guarantee their defence and protection through genuine and effective provisions. This was the mind of 1967 synodal Fathers when they provided respectively in the sixth and seventh principles for the revision of Code on the need for safeguarding people's rights and creating procedures for its protection.

Finally, it is therefore necessary to proclaim in Canon Law that the principle of juridical vigilance is to be applied in an equal way to superiors and subjects, in such a way that any suspicion of arbitrariness in ecclesiastical administration disappears (Arrieta, 2000).

\section{THE CHALLENGES OF KNIGHTS IN THE CHURCH}

\section{The Faith Challenges}

We still experience that some are still tied to traditional medicinal options by having protective medicines, belonging to secret societies and cults, going to fortune tellers, women marrying women, prosecuting cases to idols, participation in traditional festivalsand practices contrary to Christian faith, engaging in ritual purifications by the individual concerned or under the directive or instigation of others or some perform such rites on behalf of the member of the family whether with his or her consent or not and sending food to idols to pacify or in compliance with ancient directives, or believing that someone real or imagined has tied your fortunes and successes etc.

The prophetic message especially that of prophet Jeremiah is hard on those who choose other deities instead of the Almighty and Powerful Lord. It made God to frown at our entreaties unto Him (Jer 7:16-20). It destroys our group action in prayers for salvation because of what many people, especially those that call themselves Christians do in secret against their faith.

Syncretism kills a great and noble person (ihu na abo n'egbu dike). Shun the worship of idols (1 Cor 10:14). Joshua (24:14-15; also 2 Cor 6: 14-16 and John 6: 69: "Lord to whom shall we go you 
have the message of eternal life") exhorted the people of God at Schechem thus:

Now therefore fear the Lord, and serve Him in sincerity and in faithfulness; put away the gods which your fathers served beyond the River, and in Egypt, and serve the Lord. And if you be unwilling to serve the Lord, choose this day whom you will serve, whether the gods your fathers served in the region beyond the River, or the gods of Amorites in whose land you dwell; but as for me and my house, we will serve the Lord

The Church exists to proclaim the Gospel in season and out of season (2 Tim 4:1). We should speak against unjust social order and not be guilty of conspiracy of silence. Brookman (1982; also John Paul II, 1983: can 747, §2; Obiefuna, 1993; Okafor 1998): "One cannot compromise principles or be silent about the injustices, without risking being branded as an accomplice in them"(p. 63). We are currently challenged to preach the gospel in the context of our culture. What understanding do we give to our culture? What understanding do we give to our cultures? The missionary documents especially the fathers of Second Vatican Council emphasize dialogue between the gospel and culture of our people in these words: "By her activity, whatever good is found sown in the hearts and minds of men, or in the rites and cultures proper to various peoples, is not only saved from destruction, but is also healed, ennobled and brought to perfection, for the glory of God, the confusion of devil and the happiness of men...." (Vatican II, 1964: LG 17, see also SC 37). There are other experiences of spiritual attacks on the Christians, poisoning and evil wishes.

Prayer is the only weapon before us within our environment crowded with conflicts between principalities and powers. It is the divine armour that endows us with the required resources to hold our ground and resist negative influences on our calling to authentic Christian lives (Eph 6:12). The life of Jesus and the Apostles were always in prayer. Jesus taught the disciples "Our Father" (Matt 6: 714; Luke 11:1-4; Mark 11:25-26) and invites us to pray always (Luke 18:1) to ask and it shall be given unto us (Matt 7:7; Mark 11: 24)

The Church has offered us essential means to reach our God in prayer. The primary prayer and means of worship remains the Holy Sacrifice of the Mass and the adoration of the Most Holy and Blessed Eucharist. Others include: the Rosary, the Stations of the Cross, Private and Public Devotions and of course our Prayer meetings in most religious and pious societies. This is the mind of the Church legislator when it declared: "The Church carries out its sanctifying office by other means also, whether by prayer, in which it asks God to make Christ's faithful holy in the truth, and by works of penance or charity, which play a large part in establishing and strengthening in souls the Kingdom of Christ, and so contribute to the salvation of the world. Local Ordinaries are to ensure that the prayers and the pious and sacred practices of the Christian people are in full harmony with the laws of the Church" (John Paul II, 1983: can 839, §§ 1, 2; also can 392).

For us Christians we should endeavour to prioritize our prayer because by this we demonstrate the level of our faith. We should not place our prayer meetings before the Mass or avoid prayers of the entire parish community for the prayers sessions of our association. On the one hand, we should have more moments of listening just like Samuel who said: "Speak Lord your servant is listening" (1 Sam 3:10) and not the other way round, seen in most of our prayers i.e. 'Listen Lord your servant is talking and speaking on the top of his voice.' On the other hand, we should have time for prayers and give higher concentration (without the distractions of this world) to our prayers. 


\section{Challenges of Love in the Church and Family}

The Christian is identified by the possession of the greatest gifts, that is the gift of love (1 Cor 13:13; Gal 5: 14). By this all men will know that you are my disciples if you have love for one another (John 13:35). In his words St Paul (1 Cor 13: 4-8) said: "Love is patient and kind; it is never jealous; love is never boastful or conceited; it is never rude or selfish; it does not take offence, and is not resentful. Love takes no pleasure in other people's sins but delights in the truth; it is always ready to excuse, to trust, to hope, and to endure whatever comes. Love does not come to an end."

We have an option to love the Church and the visible ecclesiastical authority. This is our noble challenge since we were selected because of dedication and obedience to church affairs and welfare. Jesus Christ has assured us on the continued existence of the Church in the midst of many tribulations through his prayer on Peter (Matt 16:16-20). The Church has weathered the storm of Italian Renaissance, English Reformation and French Revolution. The Church has responded to issues of Pentecostal upsurges and the issue of Church and Churches (Vatican II, 1964: UR). Christ founded the Church on Peter and entrusted her direction and discernment in the Church to the Popes and Bishops in communion with the Pope. This is the reason, the legislator exhorted the Christian faithful to obedience to the leaders of the Church and their teachings: "Christs' faithful, conscious of their own responsibility, are bound to show Christian obedience to what the sacred Pastors, who represent Christ, declare as teachers of the faith and prescribe as rulers of the Church" (John Paul II, 1983: can 212, §1; see also cann 274, 590, 750-754).

We are invited to embrace love, fellowship and fraternization with all Christians especially within the Catholic fold. There is no need for signs of separation and disunity among one another. The Eucharist, which we receive, invites us to show love with which
Christ loved us even unto death. Let us not defile the Eucharist by leading scandalous and sacrilegious lives and thus behaving in the midst of our brothers and sisters be it within the same faith, the same family, kindred, village, town and other Churches. We should endeavour to be at peace with ourselves, our brothers and sisters. "Tear your heart and not your garment" says Prophet Joel. Live in peace with one another. The Psalmist (132:1) exclaimes "How good and how pleasant it is, when brothers live in unity;" and Ben Sirach (25:1) added: "There are three things my soul delights in and which are delightful to God and to men: concord between brothers, friendship between neighbours and a wife and a husband who live happily together."

We should shun feelings of hatred for one another or willing that evil befall your brother or sister (in blood and in faith). This is unchristian and uncharitable since "He who hates his brothers and sisters is a murderer, and as you know, eternal life does not remain in the murderer (1 John 3:15). For this reason St Peter invites us thus:

The end of all things is at hand; therefore keep sane and sober for your prayers. Above all hold unfailing in your love for one another, since love covers a multitude of sins. Practice hospitality ungrudgingly to one another. As each has received a gift, employ it for one another, as good stewards of God's varied grace: whoever speaks, as one who utters oracles of God; whoever renders service as one who renders it by the strength which God supplies; in order that in everything God may be glorified though Jesus Christ. To Him belong glory and dominion forever and ever. Amen. (1 Pet 4: 7-11).

Today, more than ever, our Christian families are tossed up 
and down by all sorts of predicaments and mentalities, as observed by Pope John Paul II in Post Synodal xhortation on the Family in Modern World, Familiaris Consortium, FC (1981),

On the one hand, in fact, there is a more lively awareness of personal freedom and greater attention to the quality of interpersonal relationships in marriage, to promoting the dignity of women, to responsible procreation, to the education of children.... On the other hand, however, signs are not lacking of a disturbing degradation of some fundamental values: a mistaken theoretical and practical concept of the independence of the spouses in relation to each other; serious misconceptions regarding the relationship of authority between parents and children; the concrete difficulties that the family itself experiences in the transmission of values; the growing number of divorces; the scourge of abortion; the ever more frequent recourse to sterilization; the appearance of a truly contraceptive mentality.(FC 6).

Included in these predicaments, continues John Paul II, are also

The spread of divorce and of recourse to a new union, even on the part of the faithful; the acceptance of purely civil marriage in contradiction to the vocation of the baptized to be married in the Lord"; the celebration of the marriage sacrament without living faith, but for other motives; the rejection of the moral norms that guide and promote the human and Christian exercise of sexuality in marriage (1981: FC 7).
The youths constitute the life-wire and future of the Church and society (John Paul II, 1997: No 46; Ngwoke, 1990; Okafor, 1997, in Chiegboka, 1999). In the Church, they are present in most lay associations especially the statutory organizations like, CYON, YCS, NFCS, CBO, CGO, Mary League Guilds, Man of Order (MOD), Man of War (MOW), Scouts, etc. and in many pious organizations especially Catholic Charismatic Renewal and CBIU.

Regrettably, our youths are submerged in very serious predicaments in the world of today. In St Paul's words (Phil 3: 1819): "I have told you often, and I repeat it today with tears, there are many who are behaving as the enemies of the cross of Christ. They are destined to be lost. They make foods into their god and they are proudest of something they ought to think shameful; the things they think important are earthly things." In addition to this, John Paul II (1998: No 1), a great lover of the youths, aptly captured the predicaments of the youths in his address for the celebration of 1998 World Youth Day, when he said: "the world in which we live is being rocked by crisis of various kinds. Young people are open to corruption, diseases, cultism, alcoholism, sexual perversion, unemployment, drugs, etc, in their search for meaning, and end up with such substitutes which lead them ultimately to despair rather than to happiness."

In Nigeria, for instance, the theme of 2008 Catechetical Week which was celebrated from October 7 to 14 was "Pastoral Care of the Youth: A Challenge to the Church in Nigeria." In the booklet for the celebration published by the National Association of Directors of Religious Education (NADRE) for the Catholic Bishops Conference of Nigeria (CBCN), certain crises/crimes are associated with the youths which include: drug addition, political thuggery, cultism/demonism, unemployment/educational admissions and fallen standards, sexual immorality (premarital sex, teenage pregnancy, prostitution, trafficking for sex trade, abortion, venereal diseases, HIV/AIDS pandemic, 
trial marriage, sexual abuse, immodest dressing, pornography, homosexuality, masturbation etc), smuggling, drunkenness, exam malpractices, armed robbery, faking and forgery (419 syndrome/ scheme), religious riot (jihad), foreign visa Madness, Quick wealth syndrome, alienation from ones root, family, emotional disorder, depression, ruined future and suicide, Pentecostalism, Practical Atheism, Alienation from their traditional roots, etc. (NADRE, 2007; see also Okafor, 1997 in Chiegboka, 1999).

We therefore invite you all, parents (husband and wife) to love and take care of one another; children should honour and respect their parents, while parents are obliged to show love care and understanding towards their children and to all in the family (Eph 5: 21- 6:1-9; Col 3:18-4:1). We should adopt an inclusive and accommodating language that is devoid of division and distinctions in our community like: amurununo and amurunamba; projeny and dignity of male and female children; extended family system outreach. How do we make demands in the home of our brethren during funerals? Do we consider the traditional option of solidarity and concern for the bereaved or do we make burdensome demands?

\section{The Truth Challenges}

The dialogue between Jesus and the woman of Samaria opened up yet other important requisites for the worshippers of God. Jesus declared clearly: "But the hour will come -in fact it is here alreadywhen true worshippers will worship the Father in spirit and truth; that is the kind of worshipper the Father wants. God is spirit, and those who worship must worship in spirit and truth" (John 4: 23).

At present our communities and families are destroyed by insincerity and lies. We tell lies in our business lives and worst in our mode of accountability. People steal from the Church and other human organizations/associations. We see deception and fraud in our actions (i.e. kick backs, forged receipts, extortions, inflated budgets, gang-ups) just like that manifested by Ananias and Sapphira in the early Church (Acts 5:1-11).

Christ enjoins us today to speak the truth. Our people say "Eziokwu bu ndu" (truth is life). Truth should therefore be in the lips of Christians, title holders both in the Church (e.g. Knights) and in our cultural societies. This is our challenge as St Paul (Eph 4: 25-32) exhorted:

Therefore, putting away falsehood let everyone speak the truth with his neighbour, for we are members one another, be angry but do not sin: do not let sun go down on your anger and give no opportunity to the devil. Let the thief no longer steal, but rather let him labour, doing honest work with his hand, so that he may be able to give those in need. Let no evil talk come out from your mouths, but only such as is good for the edifying as fits the occasion, that it may impart grace to those who hear. And do not grieve the Holy Spirit of God, in whom you were sealed for the day of redemption. Let all bitterness and wrath and anger and clamour and slander be put away from you with all malice and be kind to one another, tender hearted, forgiving one another, as God in Christ forgave you.

We should therefore avoid all false witnesses and perjury, that lead to condemnation of the innocent, exoneration of the guilty or the increased punishment of the accused (John Paul II, 1983:cann 1368, 1390, 1391; John Paul II, 1992:CCC 2476); respect the reputation of others (John Paul II, 1983:can 220), avoid rash judgment, calumny, detraction (that is without valid reasons discloses another's faults and failings to persons who did not know them-Sir 21:28) and lies, breach of professional secrecy (John Paul II, 1992: 


\section{2477-2492).}

\section{The Community Challenges}

Ours seem to be the hour of crisis in our communities especially within the various parish communities. Conflict is always a struggle between two opposing principles, aims, feelings, interests or perceptions. It is a social condition where often people pursue mutually exclusive or incompatible goals. In her opinion, Okure (2002) holds that: "Conflict describes and characterizes situations marked by the absence of peace.... Conflict can exist at any number of levels, personal, inter-personal, communal and inter-communal. It can take any number of forms: political, religious, economic. It can be rooted in race, class or gender. Whatever its form, the underlying issue in conflict is a lack of justice (not simply retributive or social justice), but justice which is "truth in relationships", the truth about self, about self in relation to others, to nature and to God." (p. 2).

The reality of crisis within the diocesan community is an ill wind that does not blow anyone any good. This is because conflicts create divisions and hatred among blood relatives, give birth to insecurity and cripple development initiatives and activities in our communities (Chiegboka, 1999; Okafor, 2002, Obiefuna, 1993)

What are the reasons for these conflicts in our communities? St James (4: 1-3) placed the origin of conflict inside the human person in these words: "Those conflicts and disputes among you, where do they come from? Do they not come from your cravings that are at war within you? You want something and do not have it; so you commit murder. And you covet something and cannot obtain it; so you engage in disputes and conflicts.... You ask and do not receive, because you ask wrongly, in order to spend what you got on your pleasures." (Chiegboka, 2002) had earlier summarized the possible reasons for conflicts in our community to include:
Disordered directives and lack of uniform implementation; Personality clashes and nature of priests in those areas especially in multi-parishes; Selfishness; Lack of good human relationships and ordered emotions; Administrative error, wrong approach to conflicts and dependence on gossips; Societal error; Neo-paganism, church/culture conflicts and absence of dialogue and lack of enthusiasm in understanding the Church's position towards culture; Inherited divided Christianity; Ignorance of Church legislation; New Idols in the community that is wealth, women, wine, personality reverence, politicians in Church sanctuary; Intrigue; Complacency, delays and lack of courage in issues; Accountability, Church property seen as benefice; Priests emphasis on traditional authority and desire for sole administrative system; Lack of adequate formation in issues of social justice, management of crisis and leadership ethics; Non recognition of the status of the laity in governance of the Church (c.129) etc. (pp. 4-5).

But how can we build peace without option of justice and forgiveness. John Paul II (1997) adviced: "No process of peace can ever begin unless an attitude of sincere forgiveness takes root in human hearts. When such forgiveness is lacking, wounds continue to fester, fuelling in the younger generation endless resentment, producing a desire for revenge and causing fresh destruction. Offering and accepting forgiveness is the essential condition for making the journey towards authentic and lasting peace." (no. 1).

\section{Political Challenges}

The distinguishing mark of the Christian laity is his dual identity and sectors of operation in both the Church and the civil society or 
political community. The Fathers of Second Vatican Council said "The lay apostolate, in all its many aspects is exercised both in the Church and in the World" (AA No 9). These two sectors, Catholic men and indeed all the members of the Laity are made citizens of the Church and the State (AG 21). These, as it were, are the enabling environment for the operations of the Knights.

The Catholic Bishops' Conference of Nigeria ( $\mathrm{CBCN}$ ) rightly observes that our nation is sick and "profoundly distressed even traumatized" (Schineller, 2002: 314-316). Nigerians are finding it increasingly difficult to be proud of their nation both internally and externally in many ramifications. We are consistently and currently subjected to cloudy and derailed political climate, programs and systems. Bribery, corruption and fraud is on the increase. Our leadership classes both military and civilian have not given the nation eloquent services for the growth of the nation. There is perceived widespread dilapidation of essential services such as roads, schools, hospitals and public utilities and continued tensions, conflicts and conflagrations, based normally on ethnic/religious affiliations. Finally, we are currently faced with the realities of social injustice and the need for social transformation. But as Kukah (2002) remarked very truly that,

It is very difficult now to encourage Nigerians about the values of democracy. The causes of our frustrations are many: deceit of the political class, betrayal by the military, deepening persistence of poverty, display of greed and conspicuous consumption etc. There is also the tendency to equate our frustration with individuals or see the need to defend democracy as being synonymous with defending individuals or parties. Nothing could be further from the truth. Sadly, this is the natural legacy of authoritarianism" (p. 9).
But we cannot give up the struggle or abdicate our civic right and political responsibility for few greed and corrupt politicians to continue to display these anomalies over and over again.

But we should declare like the people of the old, "I have seen the affliction of my people... and have heard their cry because of their taskmasters. I know their sufferings and I have come down to deliver them" (Ex 3, 7-8). These words from the Old Testament go a long way to buttress divine commitment to human liberation. It manifested itself in the life of Christ (Luke 4:18-19, Is 61:1-2) and that of the prophets and the apostles. Christ is known to be at the forefront of liberation of people. He spoke against the attitude and errors of the Pharisees, Sadducees, Scribes, Publicans, lawyers (Luke 11:45-47) and particularly against political leaders like Pilate whom he called "bloody thirsty tyrant" (Matt 18:1-3) and Herod whom he described as a "fox" (Matt 23:31-32).

The Church, therefore, is committed to this program of redemption of man and society as the Holy Father, Pope John Paul II (1979) provided: "Christ did not remain indifferent in the face of the vast and demanding imperatives of morality nor could the Church. In the spirit of the Church, which is the spirit of Christ, and relying upon her ample and solid doctrine, the Church intervenes in social matters" (p. 260). It is both natural, a right and a duty for the Church to be involved in social transformation as Pope Paul VI (1971) exhorts, "action on behalf of justice and participation in the transformation of the world fully appears to us as a constitutive dimension of the preaching of the gospel or in other words of the Church's mission for the redemption of the human race and its liberation from every oppressive situation" (no. 6).

The jurisdiction of the laity extends to both the Church and the social milieu. This is the position of the Fathers of the Second Vatican Council, the New Code of Canon Law and the articulated exhortation to the Catholic Laity of Nigeria by the Holy Father, Pope John II (1982): 
Having been called by Christ Himself, you are his chosen partners in evangelization. As lay people you know that your special apostolate is to bring Christian principles to bear upon the temporal order, that is to bring the spirit of Christ into such spheres of life as marriage and family, trade and commerce, the arts and the professions, politics and government, culture and national and international spheres. In all these areas, lay people must play their distinctive roles. In the society, you are called to be the leaven for Christ, to witness to Christ in the school, in the government office, in the town development union, in age grade meetings, in the university, in the market, in the trade union and in politics. In all these secular states, you will promote justice, unity, honesty and public spiritedness. Together you seek gospel-inspired and concrete answers to problems of bribery and corruption, lack of discipline and enthusiasm and other such ills. (p. 7).

They laity are neither visitors to the Church, nor should they succumb to position of by-standers or be indifferent to the social situation of our country, especially the political sector and state machinery. Hence added Arinze (1990), "Party politics is his closer area of Apostolate. The Catholic layman may, and should engage in party politics otherwise he could become irrelevant in society, or an apostolic balloon. Indeed, it is largely through the political activity of the layman that the Church can be made present in the world of today" (p. 66).

The lay person can accomplish this task, only in communion with God and the Church (can 209) shown in sound moral principles. They cannot transform the ills of the society or be truly the salt of the earth and the light of the world, if they are found wanting in moral authority. Hence CBCN (1993) exhorted, "In this critical period of our history, we exhort all our followers to rededicate themselves to the principles of our Catholic faith and morals. We must all take on the challenge of personal holiness, which must show itself in positive active involvement in the world around us. Jesus calls each of us to be a light in the darkness, salt of the earth and a leaven of goodness in our corrupt society" (p. 2).

The choice of democratic system of government in Nigeria is in line with our Christian and world option (Sagah, 1998) against dictatorial government, because of situations of conflicts, poverty, enrichment of few, famine and frustrations of trade unions and free press. In our country we are envisaging a situation tantamount to military dictatorship as many current office holders prepare to use the power of incumbency to thwart the required free and fair democratic culture. We have in many states a neo-dictatorship entrenched by the civilian government. Most of them have failed the country in many aspects of leadership. The brand of their leadership is extortion and siphoning of the government treasury for their private pockets and for their few friends and relations in the name of contracts. The life they live while in office is a contradiction of their manifestos during election campaigns. There are stories of institutionalized violence and thuggery. As a way to sanitize this unfortunate situation, the Catholic Bishops recommended the need for the politician to be:

God fearing and respectful of the rights of the people. He must be irreproachable, self-controlled, modest, a good teacher by word and example. He or she must not be addicted to drink. He ought not be contentious with foul language or speak half-truths to mislead, but rather be gentle, peaceful, and considerate of others' views interests. Politicians deserving our votes must be straightforward, 
intelligent, truthful and trustworthy.

The Bishops of Owerri Ecclesiastical Province (2002) added their exhortation to the electorate and our laity in these words:

In our present civil dispensation, we admonish the masses to be always conscious of the fact that sovereignty lies with the people. It is their right to choose or change their leaders in a free and fair election, which is the benchmark of a true democracy. We need to stress that Christians cannot afford to be indifferent to their civic responsibility of voting at political elections in a responsible manner. To do otherwise would mean giving approval to the prevailing political situation, no matter how bad or allowing corrupt, incompetent or inept politicians to be elected into power. Following the dictates of conscience, Christians are to vote for the right persons without being swayed by corrupt politicians through intimidation, bribes or promises of gratification. We appeal specially to the young not to allow unscrupulous politicians to use them as political thugs to intimidate their opponents or serve as corrupt agent who buy off ballot papers from the poor and the ignorant (p. 5).

But how can we accomplish this if our laity are not involved and committed to their unique dignity and duty to transform the sociopolitical situation of our country.

The Christian laity should rise now to these challenges of social transformation, that is, giving birth genuine leaders with proven integrity, informed conscience and uprightness (Kii 1998). This is your hour to change the society for better and for the future of our children. There is no sitting on the fence or allowing oneself to be locked up in a conspiracy of silence. All hands should be on deck.
There should be solidarity with all God fearing persons for the renewal of our nation.

\section{CONCLUSION: RESOLUTION TO DEFEND FAITH (1 Pet 3:15) AS KNIGHTS}

All of us Christians are given the mandate to preach the Gospel and to witness to our faith in the midst of these evil days and time. The Lord himself enjoins us to "Go and Preach" to all peoples and all creatures (Matt 28:18-19; Mark 16:15; Luke 24:14: Acts 1:8; 9:13; 28:28; John 20:17). St Paul Continued:

I charge you in the presence of God and of Christ Jesus who is to judge the living and the dead and by his appearing and his kingdom: preach the word, be urgent in season and out of season, convince, rebuke and exhort, be unfailing in patience and in teaching. For the time is coming when people will not endure sound teaching, but having itching ears they will accumulate for themselves teachers to suit their own likings and will turn away from listening to the truth and wander into myths. As for you, always be steady, endure suffering, do the work of an evangelist, fulfill your ministry. For I am already on the point of being sacrificed; the time of my departure has come. I have fought the good fight, I have finished the race, I have kept the faith. Henceforth there is laid up for me the crown of righteousness which the Lord, the righteous judge, will award to me on that day, and not only to but also to all who have loved his appearing. (2 Tim 4:1-8).

This mandate is a call to witness and to defend our faith in the world by our eloquent lives that follow the demands of the Gospel of 
our Lord Jesus. We should walk in the Spirit by avoiding all selfindulgent passions (1 Tim 1: 6-9, 13-14).

\section{REFERENCES}

Arrieta, J. I (2000). Governance Structures within the Catholic Church, Gratianus.

Beal, J. P. (1991). On Due Process: The Third Decade, in Protection of Rights of Persons in the Church; Revised Report of the Canon Law Society of America on the Subject of Due Process. Bull, G. (1982). Inside the Vatican. Britain: Hutchinson \& Co., Ltd.

Catholic Bishops' Conference of Nigeria, (2002). in Schineller, ed. Pastoral Letters and Communiques of the Catholic Bishops' Conference of Nigeria 1960-2002: The Voice of the Voiceless, Ibadan: Daily Graphics Nigeria Limited.

Chiegboka, A. B. C. (1997). Go Forth and Bear Fruits Enugu: Pearl Functions Limited.

Chiegboka, C.A. ed (1998). Simon Simon Confirm your Brethren Luke 22:31-32: Pastoral

Exhortations of Most Revd Dr Simon Akwali Okafor, Catholic Bishop of Awka. Enugu: Pearl Functions Ltd.

Chiegboka, A. B. C. (2001). The Hour of Women. Nimo: Rex Charles \& Patrick Ltd.

Chiegboka, A. B. C. (2003). Human Trafficking: Our Responsibility. In Bigard Theological Studies, 23/1 (Jan-June 2003), pp. 6377.

Chiegboka, A. B. C. (2006). 'We Cannot Be Silent': The Catholic Bishops' Conference of Nigeria on the State of the Nation. In Encounter, 7 (2006), pp. 14-31.

Coriden, J. A. (1990). What became of the Bill or Rights? In CLSA Proceedings, vol 52, pp. 47-60.

Flannery, A. ed. (1981). Vatican II Council: The Conciliar and Post Conciliar Documents. Dublin 1: Dominican Publications, 1981 (i.e. Dogmatic Constituition on the Church, Lumen gentium, Nov. 21, 1964, AAS 57 (1965) 5-75; Pastoral Constitution Gaudium et Spes, Dec. 7, 1966, AAS 58 (1966) 728-739; decretum Apostolicam actuositatem, Nov. 18, 1965, AAS 59 (1966) 837-864; decretum Ad gentes divinitus, Dec. 7, 1965, AAS 58 (1966) 947-990)

John Paul II, (1983). The Code of Canon Law in English Translation, London: Collins.

John Paul II, (1981). Post-Synodal Apostolic Exhortation on Mission and Vocation of Family in the Modern World, Familiaris consortio (FC), November 22, 1981, Vatican City, Libreria Editrice Vaticana.

John Paul II, (1988). Apostolic Letter on the Dignity and Vocation of Women in the World, Mulieris Dignitatem (MD), August 15, 1988, in AAS, 80 (1988), pp. 1653-1729.

John Paul II, (1992). The Catechism of the Catholic Church (CCC), Kenya, Pauline Publications.

John Paul II, (1982). Message to CBCN during Pastoral Visit to Nigeria Feb 15th at Lagos.

John Paul II, (1997). Message on World Peace Day, Offer Forgiveness, Receive Peace. January $1^{\text {st }}$. Retrieved from www.vatican.va.

John Paul II, (1998). Message on World Youth Day. Do Whatever He tells you. Retrieved from www.vatican.va.

Kii, P. B. (1998). Priests and Laity in Politics, Enugu: Snaap Press Ltd.

Kukah, M. H. (2002). Some Thoughts on the Church, Politics and National Reconciliation in Nigeria. Paper presented at the $70^{\text {th }}$ Birthday Lecture of His Eminence Francis Cardinal Arinze at Onitsha $30^{\text {th }}$ August.

Obi, C. A. (1985). Eminent Missionaries. In Nwosu V. A. ed. The History of Catholic Church in Onitsha. Nigeria: Etukokwu Press.

Obiefuna, A.K. (1993). Septemeber $1^{\text {st }}$ Message to Priests at 
Location Meeting. Okpuno.

Obiefuna, A.K. (1996). Letter to Priests of the Archdiocese May 15. Okafor, J. (2001). Knighthood: A Secret Society? Makurdi: Onaivi Printing \& Pub. Co. Ltd.

Okafor, S.A. (1998). We Ought to Love One Another: Invitation to Fraternal Solidarity. New Year Message to Priests Jan 7, Okpuno.

Okafor, S.A. (2002). Collaborating in Peace. New Year Message to Priests Jan 9, at Okpuno.

Okafor, S.A. (2002). Synod Acta of the First Synod of Awka Diocese. Nimo: Rex Charles \& Patrick Ltd.

Okure, T. (2002). 'The Maiden is With Child' (Isa 7:14): A Divinely Human Recipe for Conflict Resolution. Paper presented at $13^{\text {th }}$ CIWA Theology Week March 18-22, PH.

Omutah, E. P. (2004). These Men we call Knights: Papal Knighthood and Awards. Onitsha, MAS Founders Publications Ltd.

Onaiyekan, J. (1998). The Ethical \& Moral Imperatives of Governance, Paper presented at the Seminar of JDP Department of CSN Lagos.

Paprocki, T. J. (1990). Rights of Christians in the Local Church: Canon Law Procedures in Light of Civil Law Principles of Administrative Justice. In Studia Canonica, vol 24, pp. 427-442.

Sagah, I. E. (1998). Democracy and Civil Society. Paper presented at the Seminar of JDP Department of CSN, Lagos.

Shiweobi, G. E. (1992). Understanding the Catholic Knighthood. Owerri: Seminary Publications.

Unegbu, R. O.(2002). Knighthood in Nigeria Second Edition: Brief History of Christian Knighthood with Guiding Words of Wisdom and Prayers. Enugu: Our Saviour Press Ltd.

Webster's Encyclopedic Unabridged Dictionary of the English Language, (1998) NY: Gramercy Books,

The New Websters Dictionary of the English Language. (1995).
New York: Lexicon International Pub Guild Group.

Woestman, W. H. ed., (2002). Papal Allocutions to the Roman Rota 1939-2002. Ottawa: St Paul University. 